\title{
RELIABILITY AND OPERATING PROPERTIES OF THE ELECTRONIC SAFETY SYSTEM USED FOR UNINTENDED ELECTROMAGNETIC RADIATION SOURCES
}

\author{
Mirosław SIERGIEJCZYK ${ }^{1}$, JACEK Paś ${ }^{2}$, Adam ROSIŃSKI $^{3}$ \\ ${ }^{1,3}$ Warsaw University of Technology, Faculty of Transport, Department of Telecommunications in Transport, \\ ul. Koszykowa 75, 00-662 Warsaw, Poland, ${ }^{1}$ msi@wt.pw.edu.pl ${ }^{3}$ adro@wt.pw.edu.pl \\ ${ }^{2}$ Military University of Technology, Faculty of Electronic, Institute of Electronic Systems, Division of Electronic \\ Systems Exploitations, ul. gen. W. Urbanowicza 2, 00-908 Warsaw, Poland, jacek.pas@wat.edu.pl
}

\section{Abstract}

The advanced electronic devices used in the safety systems function in a particular environment depending on the facility in which they are installed. Typically, quite diverse operating conditions occur. Thus, the proper functioning of electronic systems depends not only on the reliability of individual components constituting the system, but also on the level of electromagnetic interference that can be generated by external sources. The article presents selected issues related to the impact of electromagnetic interference on electronic safety systems. In this regard, the measurements were taken into account for a facility over which there were two power lines with a $110 \mathrm{kV}$ rated voltage, while a power line with a $220 \mathrm{kV}$ voltage was located in the near $(10 \mathrm{~m})$ vicinity. The reliability and operating analysis that takes into account the electromagnetic interference was carried out. It allows to assess various types of solutions that can be implemented in order to minimise the impact of electromagnetic interference on the operation of the electronic safety systems.

Keywords: reliability, operation, electromagnetic interference, electronic devices

\section{WŁASNOŚCI NIEZAWODNOŚCIOWO-EKSPLOATACYJNE ELEKTRONICZNEGO SYSTEMU BEZPIECZEŃSTWA UŻYTKOWANEGO PRZY NIEZAMIERZONYCH ŹRÓDŁACH PROMIENIOWANIA ELEKTROMAGNETYCZNEGO}

\begin{abstract}
Streszczenie
Zaawansowane urządzenia elektroniczne stosowane w systemy bezpieczeństwa funkcjonują w określonym środowisku uzależnionym od obiektu w jakim są zainstalowane. Zazwyczaj występują dość zróżnicowane warunki eksploatacyjne. Zatem poprawne funkcjonowanie układów elektronicznych jest uzależnione nie tylko od niezawodności poszczególnych części składowych tworzących system, ale także od poziomu zakłóceń elektromagnetycznych, które mogą być generowane przez zewnętrzne źródła. W artykule przedstawiono wybrane zagadnienia związane $\mathrm{z}$ oddziaływaniem zakłóceń elektromagnetycznych na elektroniczne systemy bezpieczeństwa. Uwzględniono przy tym pomiary dla obiektu, nad którym przebiegały dwie linie energetyczne o napięciu znamionowym $110 \mathrm{kV}$, zaś w bliskim $(10 \mathrm{~m})$ sąsiedztwie budynku znajdowała się linia o napięciu $220 \mathrm{kV}$. Została przeprowadzona analiza niezawodnościowo-eksploatacyjna uwzględniająca zakłócenia elektromagnetyczne. Umożliwia to ocenę różnego rodzaju rozwiązań, które mogą być wdrożone w celu zminimalizowania wpływu zakłóceń elekromagnetycznych na funkcjonowanie elektronicznych systemów bezpieczeństwa.
\end{abstract}

Słowa kluczowe: niezawodność, eksploatacja, zakłócenia elektromagnetyczne, urządzenia elektroniczne

\section{INTRODUCTION}

The electronic safety systems are operated under different conditions of their surrounding electromagnetic environment [3, 20]. From the scientific perspective, the environment occurring in the vast railway area is particularly interesting. The reason for this situation includes numerous intended and unintended (static and mobile) electromagnetic interference, which may interfere with the functioning of electronic devices $[8,10]$, and thus, result in a decrease in the readiness indicator value.
Since the electronic safety systems function in the transport process and provide protection for travellers [7, 13], their reliable functioning is so important $[5,14]$.

The electronic safety systems functioning in the railway transport facilities are used in the particular electromagnetic environment [11, 15, 18]. The natural electromagnetic environment shaped by the phenomena that occur on the Earth is most often seriously distorted within the railway area. It is caused by the occurrence of a large number of electromagnetic field sources radiating in intended 
or unintended ways [4]. An electrical or electronic device powered by electricity generates its own electromagnetic field. It is associated with its operation. Within the railway area, there are the electronic safety systems which should operate properly irrespective of interference having an impact on them (in the acceptable range of levels). The systems' mutual coexistence as well as their proper functioning within the railway area in the particular electromagnetic environment, and operation without the implementation of unacceptable interference to the environment were defined as electromagnetic compatibility.

The issue of assessing the impact of electromagnetic interference on the operation of railway equipment is considered in a wide sense. In the publication [6], the authors presented the issues on the Mass Rapid Transit project and the high probability (by using the electronic devices) of increasing the emissions of electromagnetic radiation to the surrounding environment. The EMC measurement results within the railway area, which allowed to assess whether the permissible levels are not exceeded, were presented. The obtained test results allowed to conclude whether the measured values meet the requirements in the scope of electromagnetic compatibility included in the IEC (International Electrotechnical Commission) standards.

A part of the research communities analyses the impact of the operation of devices used in mobile means of railway transport, among others, on the railway traffic control equipment. Such an approach was presented in the publication [19]. The emission model for electromagnetic interference emitted by the Eddy Current Brakes (ECB) system affecting the trackside equipment was presented. Such an approach, at the design stage, allows to apply the specific construction in the railway traffic control equipment in order to limit the adverse impact of electromagnetic interference emitted by ECB.

A very important issue is also the assessment of electromagnetic compatibility taking into account the impact of lightning on the operation of electronic devices used in the railway transport. The electronic devices are applied in many systems used in the railway transport (e.g., railway traffic control systems, systems installed at level crossings, GSMR (Global System for Mobile Communications Railway), visual monitoring systems, etc.). The considerations in this area were presented in the paper [21]. The previously implemented methods of protection against adverse phenomena of this type were presented. Furthermore, the solutions aimed at increasing the efficiency of protection (i.a., through arrangement of electronic devices adequate to the environmental conditions already at the design stage of systems and protective elements) were proposed.

The considerations carried out so far (presented above) in the field of electromagnetic compatibility of the electronic devices used in the railway transport do not include reliability and operational modelling. Therefore, the authors of this article decided to apply such an approach.

The article presents the measurements of the electromagnetic field emitted by high-voltage power lines running near the tested civil structures. The analysis of the obtained results allows to develop a research model of the electronic safety system, and to carry out a further reliabilityoperational analysis, taking into account electromagnetic interference.

\section{ELECTROMAGNETIC INTERFERENCE OCCURRING IN THE RAILWAY AREA}

The electromagnetic compatibility concept can be defined as the possibility of the useful signal and interference coexistence without the loss of information included in the signal. By extending the compatibility concept in the application for the electronic safety systems, the definition can be formulated as follows: an element of the electromagnetic environment of the electronic safety system is considered compatible, if the mutual interaction of a given element (e.g. control panel, expansion modules, manipulators, etc.) with other elements of this environment (e.g. rail traffic control systems, railway station lighting systems, power supply systems, railway telecommunications systems, etc.) can be mutually tolerated $[1,9]$.

The electronic safety systems operated in the large railway area are susceptible to the electromagnetic interference impact. Long distances between the individual devices, which form the system, result in the necessity to use the power supply and signal cables as well as transmission buses with significant lengths. It may be a reason for the induction of interference signals in them, and at the same time, it may cause the system malfunctioning. It is particularly important in case of functioning in their close distance from the transmission power lines. Therefore, the authors measured the electromagnetic field parameters at high-voltage power lines that run close to the tested civil structures.

The measurements were made in the adjacent area and inside the single-floor building including office rooms. Above the building, there were two power lines with a rated voltage of $110 \mathrm{kV}$. In the vicinity of the building, there was a $220 \mathrm{kV}$ voltage line, which was approximately $10 \mathrm{~m}$ away from the property.

The measurements on the property (outside the building) and in the ground floor workshop part were carried out at every $1 \mathrm{~m}$, in the direction perpendicular to the transmission lines. The ranges of the measured values of electric and magnetic fields, with a frequency of $50 \mathrm{~Hz}$, on the square in front of the building, were given in Table 1. 
Table 1. The ranges of the measured values of the electric field strength $\mathbf{E}$ and magnetic induction $\mathbf{B}$ on the premises around the building

\begin{tabular}{|c|c|c|}
\hline $\begin{array}{c}\text { Measurement } \\
\text { place }\end{array}$ & $\begin{array}{c}\text { Range of the electric } \\
\text { field strength values } \\
\mathbf{E}[\mathrm{V} / \mathrm{m}]\end{array}$ & $\begin{array}{c}\text { Range of the } \\
\text { magnetic } \\
\text { induction values } \\
\mathbf{B}[\mu \mathrm{T}]\end{array}$ \\
\hline $\begin{array}{c}\text { In front of the } \\
\text { building }\end{array}$ & $100-520$ & $0,27-0,963$ \\
\hline $\begin{array}{c}\text { Behind the } \\
\text { building }\end{array}$ & $130-550$ & $0,23-0,694$ \\
\hline
\end{tabular}

The measurements inside the building were carried out after performing a preliminary diagnosis in the entire space of each tested room. During the measurement of the electric field strength in the building, in most rooms, very low values of this parameter (a few to several V/m) were found. Only at some measurement points, $\mathbf{E}$ values of $100 \mathrm{~V} / \mathrm{m}$ or more were obtained. On the first floor, the maximum value of the field was approximately 126 $\mathrm{V} / \mathrm{m}$, and on the ground floor of the building, the value of this field reached several $\mathrm{V} / \mathrm{m}$. The reason for this is that the electric field is strongly attenuated by the ceilings and walls of the building.

The magnetic field from the power lines only slightly attenuates because building obstacles (ceilings, walls) fundamentally do not affect the propagation of the electromagnetic wave from this frequency range.

The magnetic induction values in the rooms were in the range from $0.3 \mu \mathrm{T}$ to $3.6 \mu \mathrm{T}$, with a significant variation in the value of $\mathbf{B}$ between individual rooms. The limit values of the magnetic induction $\mathbf{B}$, found on individual floors (in the tested rooms), are included in Table 2.

Table 2. The ranges of the magnetic induction value $\mathbf{B}$ in the rooms on individual floors of the building

\begin{tabular}{|l|c|}
\hline \multicolumn{1}{|c|}{ Name of the tested room (floor) } & $\begin{array}{c}\text { Range of } \\
\text { values }[\mu \mathrm{T}]\end{array}$ \\
\hline Conference room (basement) & $0.40-0.60$ \\
\hline Reception (ground floor) & $0.80-1.00$ \\
\hline Room 1 (ground floor) & $0.30-0.60$ \\
\hline Room 2 (ground floor) & $0.29-3.00$ \\
\hline Room 3 (ground floor) & $0.39-0.80$ \\
\hline Utility room (ground floor) & $0.60-1.59$ \\
\hline Workshop (ground floor) & $0.28-0.93$ \\
\hline Passageways (1st floor) & $1.80-3.20$ \\
\hline Room 4 (1st floor) & $0.99-3.60$ \\
\hline
\end{tabular}

All the measurements were carried out at positive outside temperatures and air humidity close to normal.

\section{RELIABILITY AND OPERATION ANALYSIS OF THE ELECTRONIC SAFETY SYSTEM INCLUDING ELECTROMAGNETIC INTERFERENCE}

The operation process models of the electronic safety systems used in railway transport, including electromagnetic interference, require the analysis of their functioning in actual conditions (also including the diagnostic signals $[2,16,17])$. Therefore, it is possible to obtain the relationships, which allow to determine the values of probabilities of the considered systems staying in the distinguished operation states [12].

By conducting the operation analysis of the electronic safety systems used in railway transport, including electromagnetic interference, it is possible to illustrate the relationships occurring in this structure, in terms of reliability and operation, as it is presented in Fig. 1.

If the electronic safety system is in the state of complete usability $\mathrm{S}_{\mathrm{PZ}}$ and there is electromagnetic interference (in the acceptable range), the system transits to the state of impendency over safety $S_{\mathrm{ZB} 1}$ with the intensity $\lambda_{\mathrm{ZB} 1}$. If the system is in the state of impendency over safety $\mathrm{S}_{\mathrm{ZB} 1}$, it is possible to transit into the state of complete usability $\mathrm{S}_{\mathrm{PZ}}$ with the intensity $\mu_{\mathrm{ZB} 1}$ provided that the activities on reducing the electromagnetic interference consequences are undertaken.

If the electronic safety system is in the state of impendency over safety $S_{\mathrm{ZB} 1}$ and there is electromagnetic interference (exceeding the permissible values, but the system still operates), the system transits into the state of impendency over safety $\mathrm{S}_{\mathrm{ZB} 2}$ with the intensity $\lambda_{\mathrm{ZB} 2}$. If the system is in the state of impendency over safety $\mathrm{S}_{\mathrm{ZB} 2}$, it is possible to transit into the state of impendency over safety $S_{\mathrm{PZ}}$ with the intensity $\mu_{\mathrm{ZB} 2}$ provided that the activities on reducing the electromagnetic interference consequences (to the level of permissible values) are undertaken.

If the electronic safety system is in the state of impendency over safety $\mathrm{S}_{\mathrm{ZB} 2}$ and there is electromagnetic interference (exceeding the permissible values and resulting in the system operation interruption), the system transits into the state of unreliability of safety $S_{B}$ with the intensity $\lambda_{\mathrm{ZB} 3}$. If the system is in the state of unreliability of safety $S_{B}$, it is possible to transit into the state of impendency over safety $S_{\mathrm{ZB} 2}$ with the intensity $\mu_{\mathrm{ZB} 3}$ provided that the activities on reducing the electromagnetic interference consequences (to the level exceeding the permissible values, but the system still operates) are undertaken.

If the electronic safety system is in the state of impendency over safety $\mathrm{S}_{\mathrm{ZB} 2}$, it is possible to transit into the state of complete usability $S_{\mathrm{PZ}}$ with the intensity $\mu_{\mathrm{B} 0}$ provided that the activities on reducing the electromagnetic interference consequences (to the level below the permissible values) are undertaken.

If the electronic safety system is in the state of unreliability of safety $S_{B}$, it is possible to transit to the state of complete usability $\mathrm{S}_{\mathrm{PZ}}$ with the intensity $\mu_{\mathrm{B} 1}$ provided that the activities on reducing the electromagnetic interference consequences (to the level below the permissible values) were undertaken. 


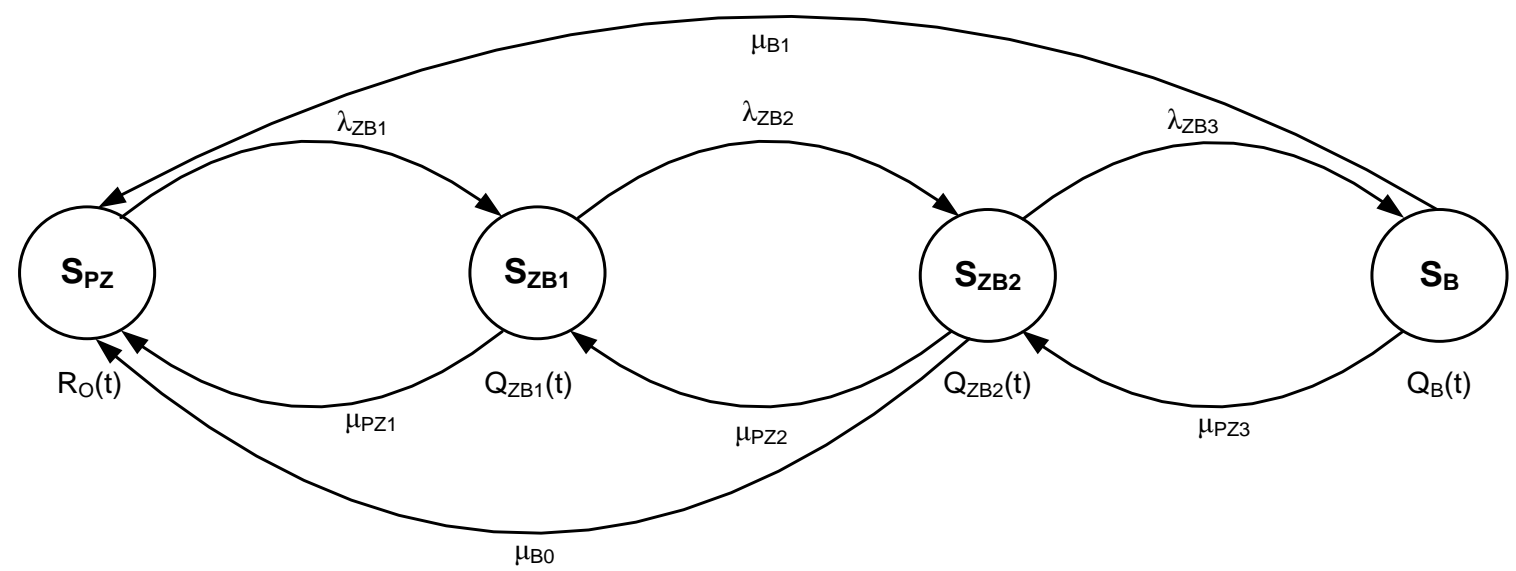

Fig. 1. Relationships in the electronic safety system including the electromagnetic interference [source: own development] Markings in Fig.: $\mathrm{R}_{\mathrm{O}}(\mathrm{t})$ - probability function of the system staying in the state of complete usability $\mathrm{S}_{\mathrm{PZ}}, \mathrm{Q}_{\mathrm{ZB} 1}(\mathrm{t})$ - probability function of the system staying in the state of impendency over safety $\mathrm{S}_{\mathrm{ZB} 1}$,

$\mathrm{Q}_{\mathrm{ZB} 2}(\mathrm{t})$ - probability function of the system staying in the state of impendency over safety $\mathrm{S}_{\mathrm{ZB} 2}, \mathrm{Q}_{\mathrm{B}}(\mathrm{t})-$ probability function of the system staying in the state of unreliability of safety $S_{B}, \lambda_{Z B 1}$ - intensity of transitions from the state of complete usability $S_{\mathrm{PZ}}$ to the state of impendency over safety $\mathrm{S}_{\mathrm{ZB} 1}, \lambda_{\mathrm{ZB} 2}-$ intensity of transitions from the state of impendency over safety $S_{Z B 1}$ to the state of impendency over safety $\mathrm{S}_{\mathrm{ZB} 2}, \lambda_{\mathrm{ZB} 3}-$ intensity of transitions from the state of impendency over safety $\mathrm{S}_{\mathrm{ZB} 2}$ to the state of unreliability of safety $S_{B}, \mu_{Z B 1}-$ intensity of transitions from the state of impendency over safety $S_{Z B 1}$ to the state of complete usability $S_{\mathrm{PZ}}, \mu_{\mathrm{ZB} 2}$ - intensity of transitions from the state of impendency over safety $S_{\mathrm{ZB} 2}$ to the state of impendency over safety $S_{Z B 1}, \mu_{Z B 3}$ - intensity of transitions from the state of unreliability of safety $S_{B}$ to the state of impendency over safety $S_{Z B 2}, \mu_{B 0}$ - intensity of transitions from the state of impendency over safety $S_{Z B 2}$ to the state of complete usability $S_{\mathrm{PZ}}, \mu_{\mathrm{B} 1}$ - intensity of transitions from the state of unreliability of safety $\mathrm{S}_{\mathrm{B}}$ to the state of complete usability $\mathrm{S}_{\mathrm{PZ}}$.

The system presented in Fig. 1 can be described by the following Chapman-Kolmogorov equations:

$R_{0}^{\prime}(t)=-\lambda_{Z B 1} \cdot R_{0}(t)+\mu_{P Z 1} \cdot Q_{Z B 1}(t)+\mu_{B 0} \cdot Q_{Z B 2}(t)+\mu_{B 1} \cdot Q_{B}(t)$

$Q_{Z B 1}^{\prime}(t)=\lambda_{Z B 1} \cdot R_{0}(t)-\mu_{P Z 1} \cdot Q_{Z B 1}(t)-\lambda_{Z B 2} \cdot Q_{Z B 1}(t)+$

$+\mu_{P Z 2} \cdot Q_{Z B 2}(t)$

$Q_{Z B 2}^{\prime}(t)=\lambda_{Z B 2} \cdot Q_{Z B 1}(t)-\mu_{P Z 2} \cdot Q_{Z B 2}(t)-\lambda_{Z B 3} \cdot Q_{Z B 2}(t)+$

$+\mu_{P Z 3} \cdot Q_{B}(t)-\mu_{B 0} \cdot Q_{Z B 2}(t)$

$Q_{B}^{\prime}(t)=\lambda_{Z B 3} \cdot Q_{Z B 2}(t)-\mu_{P Z 3} \cdot Q_{B}(t)-\mu_{B 1} \cdot Q_{B}(t)$

Assuming the baseline conditions:

$$
\begin{aligned}
& R_{0}(O)=1 \\
& Q_{Z B 1}(O)=Q_{Z B 2}(O)=Q_{B}(O)=0
\end{aligned}
$$

and applying the Laplace transform, we obtain the following system of linear equations:

$$
\begin{aligned}
& s \cdot R_{0}^{*}(s)-1=-\lambda_{Z B 1} \cdot R_{0}^{*}(s)+\mu_{P Z 1} \cdot Q_{Z B 1}^{*}(s)+\mu_{B 0} \cdot Q_{Z B 2}^{*}(s)+ \\
& +\mu_{B 1} \cdot Q_{B}^{*}(s) \\
& s \cdot Q_{Z B 1}^{*}(s)=\lambda_{Z B 1} \cdot R_{0}^{*}(s)-\mu_{P Z 1} \cdot Q_{Z B 1}^{*}(s)-\lambda_{Z B 2} \cdot Q_{Z B 1}^{*}(s)+ \\
& +\mu_{P Z 2} \cdot Q_{Z B 2}^{*}(s) \\
& s \cdot Q_{Z B 2}^{*}(s)=\lambda_{Z B 2} \cdot Q_{Z B 1}^{*}(s)-\mu_{P Z 2} \cdot Q_{Z B 2}^{*}(s)-\lambda_{Z B 3} \cdot Q_{Z B 2}^{*}(s)+ \\
& +\mu_{P Z 3} \cdot Q_{B}^{*}(s)-\mu_{B 0} \cdot Q_{Z B 2}^{*}(s) \\
& s \cdot Q_{B}^{*}(s)=\lambda_{Z B 3} \cdot Q_{Z B 2}^{*}(s)-\mu_{P Z 3} \cdot Q_{B}^{*}(s)-\mu_{B 1} \cdot Q_{B}^{*}(s)
\end{aligned}
$$

The probabilities of the system staying in the distinguished functional states from the symbolic (Laplace's) perspective have the following form:

$$
\begin{aligned}
R_{0}^{*}(s)= & \frac{b \cdot \lambda_{Z B 3} \cdot \mu_{P Z 3}-b \cdot c \cdot d \cdot s+d \cdot s \cdot \lambda_{Z B 2} \cdot \mu_{P Z 2}}{a \cdot b \cdot \lambda_{Z B 3} \cdot \mu_{P Z 3}+\mu_{B 1} \cdot \lambda_{Z B 1} \cdot \lambda_{Z B 2} \cdot \lambda_{Z B 3}+} \\
& -\lambda_{Z B 1} \cdot \mu_{P Z 1} \cdot \lambda_{Z B 3} \cdot \mu_{P Z 3}+a \cdot d \cdot s \cdot \lambda_{Z B 2} \cdot \mu_{P Z 2}+ \\
& +c \cdot d \cdot s \cdot \lambda_{Z B 1} \cdot \mu_{P Z 1}+d \cdot s \cdot \mu_{B 0} \cdot \lambda_{Z B 1} \cdot \lambda_{Z B 2}+ \\
& -a \cdot b \cdot c \cdot d \cdot s \\
Q_{Z B 1}^{*}(s)= & \frac{\lambda_{Z B 1} \cdot \lambda_{Z B 3} \cdot \mu_{P Z 3}-c \cdot d \cdot s \cdot \lambda_{Z B 1}}{a \cdot b \cdot \lambda_{Z B 3} \cdot \mu_{P Z 3}+\mu_{B 1} \cdot \lambda_{Z B 1} \cdot \lambda_{Z B 2} \cdot \lambda_{Z B 3}+} \\
& -\lambda_{Z B 1} \cdot \mu_{P Z 1} \cdot \lambda_{Z B 3} \cdot \mu_{P Z 3}+a \cdot d \cdot s \cdot \lambda_{Z B 2} \cdot \mu_{P Z 2}+ \\
& +c \cdot d \cdot s \cdot \lambda_{Z B 1} \cdot \mu_{P Z 1}+d \cdot s \cdot \mu_{B 0} \cdot \lambda_{Z B 1} \cdot \lambda_{Z B 2}+ \\
& -a \cdot b \cdot c \cdot d \cdot s \\
Q_{Z B 2}^{*}(s)= & -\frac{d \cdot s \cdot \lambda_{Z B 1} \cdot \lambda_{Z B 2}}{a \cdot b \cdot \lambda_{Z B 3} \cdot \mu_{P Z 3}+\mu_{B 1} \cdot \lambda_{Z B 1} \cdot \lambda_{Z B 2} \cdot \lambda_{Z B 3}+} \\
& -\lambda_{Z B 1} \cdot \mu_{P Z 1} \cdot \lambda_{Z B 3} \cdot \mu_{P Z 3}+a \cdot d \cdot s \cdot \lambda_{Z B 2} \cdot \mu_{P Z 2}+ \\
& +c \cdot d \cdot s \cdot \lambda_{Z B 1} \cdot \mu_{P Z 1}+d \cdot s \cdot \mu_{B 0} \cdot \lambda_{Z B 1} \cdot \lambda_{Z B 2}+ \\
& -a \cdot b \cdot c \cdot d \cdot s \\
Q_{B}^{*}(s)=- & \frac{\lambda_{Z B 1} \cdot \lambda_{Z B 2} \cdot \lambda_{Z B 3}}{a \cdot b \cdot \lambda_{Z B 3} \cdot \mu_{P Z 3}+\mu_{B 1} \cdot \lambda_{Z B 1} \cdot \lambda_{Z B 2} \cdot \lambda_{Z B 3}+} \\
& -\lambda_{Z B 1} \cdot \mu_{P Z 1} \cdot \lambda_{Z B 3} \cdot \mu_{P Z 3}+a \cdot d \cdot s \cdot \lambda_{Z B 2} \cdot \mu_{P Z 2}+ \\
& +c \cdot d \cdot s \cdot \lambda_{Z B 1} \cdot \mu_{P Z 1}+d \cdot s \cdot \mu_{B 0} \cdot \lambda_{Z B 1} \cdot \lambda_{Z B 2}+ \\
& -a \cdot b \cdot c \cdot d \cdot s
\end{aligned}
$$

where:

$$
\begin{aligned}
& a=s+\lambda_{Z B 1} \\
& b=s+\mu_{P Z 1}+\lambda_{Z B 2} \\
& c=s+\mu_{P Z 2}+\lambda_{Z B 3}+\mu_{B 0} \\
& d=s+\mu_{P Z 3}+\mu_{B 1}
\end{aligned}
$$


By conducting the further mathematical analysis, the relationships which allow to determine the probabilities of the electronic safety system staying in the states of: complete usability $\mathrm{S}_{\mathrm{PZ}}$, impendency over safety $\mathrm{S}_{\mathrm{ZB} 1}$ and $\mathrm{S}_{\mathrm{ZB} 2}$, and unreliability of safety $S_{B}$ are obtained.

The presented considerations and the developed model allow for numerical assessment of various types of solutions that can be implemented in order to minimise the impact of electromagnetic interference on the functioning of the electronic safety systems.

\section{SUMMARY AND CONCLUSIONS}

The issues presented in this article, which are related to the electromagnetic compatibility of the electronic safety systems, show the importance of the reliability and operation analysis issues. The use of numerous electronic safety systems results in the fact that they operate located close to each other. It may result in an increase of the interference probability occurrence in their operation. Therefore, while designing the electronic safety systems, it is important to take into account their operation in the actual conditions, that is among other devices. It means that the device operation should not be affected by any external sources of interference, and the electronic safety system itself should not be a source of interference (a concept of external and internal electromagnetic compatibility).

\section{REFERENCES}

1. Charoy A. Interference in electronic equipment. Warsaw: WNT; 1999. Polish.

2. Duer S, Zajkowski K, Płocha I, Duer R. Training of an artificial neural network in the diagnostic system of a technical object. Neural Computing \& Applications 2013; 22(7): 1581-1590. https://doi.org/10.1007/s00521-012-1052-9.

3. Dyduch J, Moczarski J. Podstawy eksploatacji systemów sterowania ruchem kolejowym. Radom: Wydawnictwo UTH Radom, 2015. Polish.

4. Dziubinski M, Drozd A, Adamiec M, Siemionek E. Electromagnetic interference in electrical systems of motor vehicles. IOP Conference Series-Materials Science and Engineering. 2016; 148. https://doi.org/10.1088/1757-899X/148/1/012036.

5. Laskowski D, Lubkowski P, Pawlak E, Stańczyk P. Anthropotechnical systems reliability. In: the monograph „Safety and Reliability: Methodology and Applications - Proceedings of the European Safety and Reliability Conference ESREL 2014". London: CRC Press/Balkema, 2015.

6. Loi BT, Yong R. Electromagnetic compatibility railway radiated electromagnetic emission to environment and the control methodologies. 7th Asia Pacific International Symposium on Electromagnetic Compatibility, Shenzhen, China, 2016. https://doi.org/10.1109/APEMC.2016.7523016.

7. Młyńczak J, Hejczyk T, Wszołek B, Gałuszka A, Surma D, Ogaza R, Burdzik R. Passenger safety and information module in intelligent integrated traffic management system. Vibroengineering Procedia 2015; 6: 234-237.

8. Ogunsola A, Mariscotti A. Electromagnetic compatibility in railways. Analysis and management. Springer-Verlag; 2013.

9. Ott HW. Electromagnetic compatibility engineering. Wiley; 2009.

10. Paś J. Operation of electronic transportation systems. Radom: Publishing House University of Technology and Humanities; 2015. Polish.

11. Paś J, Rosiński A. Selected issues regarding the reliability-operational assessment of electronic transport systems with regard to electromagnetic interference. Eksploatacja i Niezawodnosc Maintenance and Reliability 2017; 19(3): 375-381. https://doi.org/10.17531/ein.2017.3.8.

12. Rosiński A. Modelling the maintenance process of transport telematics systems. Warsaw: Publishing House Warsaw University of Technology; 2015. Polish.

13. Siergiejczyk M, Krzykowska K, Rosiński A, Grieco LA. Reliability and viewpoints of selected ITS system. In: Selvaraj H, Chmaj G, Zydek D, eds. Proceedings 25th International Conference on Systems Engineering ICSEng IEEE, Conference Publishing Services (CPS), 2017: 141-146. https://doi.org/10.1109/ICSEng.2017.68.

14. Siergiejczyk M, Krzykowska K, Rosiński A. Reliability-exploitation analysis of electronic power systems used for airport security. In: Čepin M, Briš R, eds. Safety and Reliability - Theory and Applications. London: CRC Press Taylor \& Francis Group; 2017: 649-654.

15. Siergiejczyk M, Paś J, Rosiński A. Issue of reliability-exploitation evaluation of electronic transport systems used in the railway environment with consideration of electromagnetic interference. IET Intelligent Transport Systems 2016; 10(9): 587593. https://doi.org/10.1049/iet-its.2015.0183.

16. Stawowy M. Comparison of uncertainty models of impact of teleinformation devices reliability on information quality. In: "Proceedings of the European Safety and Reliability Conference ESREL 2014", CRC Press/Balkema 2015: 2329-2333.

17. Stawowy M, Kasprzyk Z. Identifying and simulation of status of an ICT system using rough sets. In: Zamojski W, Mazurkiewicz J, Sugier J, Walkowiak T, Kacprzyk J, eds. Proceedings of the Tenth International Conference on Dependability and Complex Systems DepCoS-RELCOMEX, given as the monographic publishing series - „Advances in intelligent systems and computing". 2015, 265: 477484. https://doi.org/10.1007/978-3-319-19216-1_45.

18. Sumiła M, Miszkiewicz A. Analysis of the problem of interference of the public network operators to GSM-R. In: „Tools of Transport Telematics”, given as the monographic publishing series „Communications in Computer and Information Science". 2015; 531: 76-82.

19. Valderas D, Mesa I, Adín I, Lehmann H, Lancaster G, Stark O, Baldauf W, del Portillo J. Modelling Eddy Current Brake emissions for electromagnetic compatibility with signal ing devices in high speed railways. IEEE Transactions on Vehicular Technology 2017; 66(11). https://doi.org/10.1109/TVT.2017.2757089.

20. Valis D, Pietrucha-Urbanik K. Utilization of diffusion processes and fuzzy logic for vulnerability 
assessment. Eksploatacja i Niezawodnosc Maintenance and Reliability 2014; 16(1): 48-55.

21. Vašata J, Doleček R. Electromagnetic compatibility and lightning current impacts in the railway equipment buildings. In: 26th Conference Radioelektronika 2016, Košice, Slovak Republic. https://doi.org/10.1109/RADIOELEK.2016.7477417.

22. Wierzbicki S. Diagnosing microprocessor controlled systems. Teka Komisji Motoryzacji i Energetyki Rolnictwa. 2006;VI:183-188.

Received 2018-06-15

Accepted 2018-09-21

Available online 2018-09-24

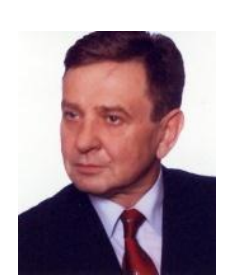

Prof. Miroslaw SIERGIEJCZYK,

$\mathrm{PhD}$. Eng. - scientific fields of interest of the paper co-author concern among other issues of architecture and services provided by telecommunications networks and systems, especially from perspective of their applications in transport, reliability and operation of telecommunications networks and systems, modelling, designing and organising telecommunications systems for transport.

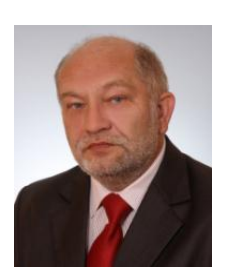

Jacek PAŚ Associate Professor PhD. Eng. - scientific interests (electromagnetic compatibility, analog circuits, reliability, low frequency noise, exploitation, diagnostics, projecting) are problems connected with comprehended wide of the safety both for stationary as well as for movable objects. He is the author of three books and more than 150 articles. His research interests include also environmental studies of electromagnetic the range at low frequencies at (electrosmog).

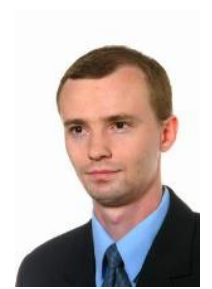

Adam ROSIŃSKI - Associate Professor PhD. Eng. - research interests include Intelligent Transportation Systems, electronics (analog and digital) and issues related to reliability, exploitation, diagnostics and design of electronic security systems (intrusion detection, video surveillance systems, access control systems, fire alarm systems, voice evacuation systems, monitoring systems, systems integration), with special regard to their use in transport. $\mathrm{He}$ has academic achievements (as author or co-author) six books and over 100 articles, and many unique solutions in the field of security of a special nature. 